\title{
The Influence of Company Size and Debt to Asset Ratio on Return On Assets
}

\author{
${ }^{1}$ Dwi Shahfira, ${ }^{2}$ Nanu Hasanuh ${ }^{2}$ \\ 1,2 Universitas Singaperbangsa Karawang \\ e-mail: ${ }^{1,2}$ d.shahfira888@gmail.comnanu, ${ }^{2}$ hasanuh@fe.unsika.ac.id

\begin{tabular}{ccc}
\hline Diterima & Direvisi & Disetujui \\
$03-08-2020$ & $22-10-2020$ & $15-03-2021$ \\
\hline
\end{tabular}

\begin{abstract}
This research purposed to identify the effect of Company Size (SIZE) and Debt to Asset Ratio (DAR) on Return On Asset (ROA). The dependent variable was Return On Assets (ROA) and the independent variable was Company Size (SIZE) and Debt to Asset Ratio (DAR). Data were obtained from the financial statement of 12 manufacturing companies in sub-sector of automotive registered on Indonesia Stock Exchange in the period 2014-2018. The study used Multiple Linear Regression Test as the data analysis method. The results show that Company Size partially had a significant positive effect on Return On Assets (ROA). Also, Debt to Asset Ratio (DAR) partially had a significant negative effect on Return On Assets (ROA). Simultaneously, Company Size (SIZE) and Debt to Asset Ratio (DAR) had effect on Return On Assets (ROA). So, the company should keep the stability of the company size and expect to perform debt management properly to optimize increasing the level of Return On Assets (ROA) and remain stable.
\end{abstract}

Keywords: Company Size, Debt to Asset Ratio (DAR), Return On Assets Ratio (ROA).

\section{INTRODUCTION}

Industrial sector is still the dominant sector in Indonesia. This sector continues to consistently provide the largest contribution to the national economy. Automotove is one part of the industry or manufacturing sector. Automative industry was choosen as the mainstay in stimulate our economy growth. The government more incentive to boost the increase in exports of this industry. Increased exports can only be done for their investment.

The company certainly makes the profit and to assess the ability of company in making profit it is used the profitablity ratio. (Kasmir, 2012). It is the role of the management to control the use of finances in institutions. One of the indicators used in profitability is ROA (Return on Assets) that is to the ability of a company to make the profit by using the company assets (Sutrisno, 2013), Return On Assets (ROA) is the comparison between overall profit of a company and overall investment of the company. Higher ROA indicates the better condition of company.

Company size is a factor that inflence Return On Asset. Company size is indicated by the sales level, number of employees, or assets owned by the company. Company size is used to see market forces and efficiency. If the company has high efficiency and substantial market power, the ROA will be higher (Rusmawati, 2016). Companies with a large asset have the potential to generate a better return because of the existence of the asset can increase the production capacity of the company (Purnamasari \&
Fitria, 2015), Total assets were great support the company can optimize the company's performance in generating assets. It is stated that there is positive relationship between company size and ROA.

Another factor affecting Return On Assets (ROA) is Debt to Asset Ratio (DAR). DAR is the ratio of total debt and total assets (Hery, 2015), The meaning of debt is all the debt of company either short or long term debt. The high value of DAR causes the bad credit of company. The lower the DAR, the better the condition of a company. Because only a small portion of assets financed with debt. If the borrowed funds the company received a greater yield than the debt, then income or profits from the company will increase. Thus there is negative relationship between DAR and ROA.

Tabel 1. Company Size, Debt to Asset Ratio (DAR) and Return On Assets (ROA) of Manufacturing Companies in Automative Sub Sector Listed on the Indonesia Stock Exchange period 2014-2018

\begin{tabular}{|c|c|c|c|}
\hline Year & SIZE & DAR (\%) & ROA (\%) \\
\hline $\mathbf{2 0 1 4}$ & 29.01 & 43.85 & 5.41 \\
\hline $\mathbf{2 0 1 5}$ & 29.15 & 46.62 & 2.67 \\
\hline $\mathbf{2 0 1 6}$ & 29.19 & 46.46 & 3.56 \\
\hline $\mathbf{2 0 1 7}$ & 29.21 & 42.31 & 9.77 \\
\hline $\mathbf{2 0 1 8}$ & 29.32 & 40.08 & 2.72 \\
\hline
\end{tabular}

Source: Bank Indonesia, data processed

Table 1 points that the size of company always increase for five consecutive years. However, this increase is not always followed by a rise in the 
average return on assets. The decrease of assets occured in 2015 and 2018. In 2015, the company size increased from 29.01 to 29.15 , while ROA decreased from $5.41 \%$ to $2.67 \%$. Similarly, in 2018 , the size of the company increased from 29.21 to 29.32 , while ROA also decreased from $6.77 \%$ to $2.72 \%$. The decline in ROA is due to the increase in assets during the year is not followed by an increase in profit. This phenomenon is not in accordance with the existing theory that the relationship sized companies with ROA are a positive relationship. On average Debt to Asset Ratio 2014 to 2017 tended to decrease. Any reduction in the average Debt to Asset Ratio is always followed by an increase in Return On Asset. Vice versa, if there is an increase in Debt to Asset Ratio, then there is a decline in Return on Assets. However, in 2018 there was a difference from previous years. 2018 DAR has decreased from $42.31 \%$ to $40.08 \%$, while ROA decreased from $6.77 \%$ to $2.72 \%$. The decrease in Debt Asset Ratio is not followed by Return On Asset. The phenomenon that occurs not in accordance with the existing theory that the DAR relationship with ROA is negative.

Previous studies show that the company size affects the Return on Assets (ROA) but some studies state that there is no effect between the company size and ROA. Similarly, Debt To Asset Ratio (DAR) on Return On Assets (ROA). There are several studies performed in company in different periods.

Previous studies conducted by (Meidiyustiani, 2016), stating that company size has negative effect on ROA. Different with the study of (Rusmawati, 2016) which revealed that there is positive effect of company size on ROA. These results differ from studies conducted (Nurdiana, 2018) which states there is no effect of Company size on ROA.

The study carried out by (Darmawan \& Nurochman, 2016) states that DAR has significant negative effect on ROA. In contrast to study conducted (Mailinda, Azharsyah, \& Zainul, 2018) that shows a positive siginificant effect of DAR on ROA. While the research conducted by (Zulkarnaen, 2018) there is no influence of Debt To Asset Ratio (DAR) on Return On Assets (ROA).

This study aimed to analyze the effect Company Size (SIZE) and Debt to Asset Ratio (DAR) on Return On Asset (ROA) of manufacturing companies in automotive sub-sector listed on Indonesia Stock Exchange. This study also purposed to identify the effect of company size to the debt of asset ratio return on assets using multiple linear regression test for analysing the data.

\section{Literature Review}

1. Return On Assets (ROA)

(Hery, 2015) reveals that ROA is a ratio that shows the assets contribution in making the net profit. ROA is for measuring company effectiveness to results the earning from available assets and measure the efficiency of a company. The high level of ROA in the company shows the company's profit generated from asset management within the company can be said to be good. ROA is indicator that illustrates financial performance of a company. The higher value of ROA in a company shows that the financial performance is good.

\section{Company Size}

According to (Riyanto, 2013) company size can be assesed from the equity, sales or total assets. Company size is according to the total assets of the company. Great company size is dute to great assets owned. The greater assets, the greater capital investment, but the more sales of company the more debt cycle. (Sujarweni, 2015). According to (Halim, 2015) the larger the size of companies, the tendency of using foreign capital is also getting bigger. This is because large companies need large funds to support their operations, and one alternative is to complete capital with foreign capital if their own capital is not sufficient.

\section{Debt to Asset Ratio (DAR)}

(Hery, 2015) states that Debt to Assets Ratio is to measure the total debt to total assets. Moreover, the use of DAR is to quantify the effect of company debt to the financing assets. (Kasmir, 2016) states that if a DAR is high, it is increasingly difficult for the companies to get additional loan, because the company is worried to cover the debts of the assets. Based on these opinions, the higher DAR, the greater company's debt and vice versa.

\section{Hypothesis}

H1 : Company size partially has an influence on Return On Assets (ROA).

$\mathrm{H} 2$ : Debt to Asset Ratio (DAR) has partially influence on Return On Assets (ROA).

H3 : Company size and Debt to Asset Ratio (DAR) simultaneously have an influence on Return On Assets (ROA).

\section{METHODOLOGY}

\section{Research Population and Samples}

Samples were obtained by purposive sampling technique and met the following criteria: (1) Listed Automotive sub-sector manufacturing companies in the Indonesia Stock Exchange, (2) Automotive subsector manufacturing companies that have financial reports during the 2014-2018 research period, (3) Automotive sub-sector manufacturing companies that use the Rupiah currency in reporting financial statements, and (4) The companies with complete data between 2014-2018. The sample involved 12 companies with 60 observations. 


\section{Operational Definition}

1. Company Size (Size)

In this study, the measurement of company size was proclaimed by SIZE. SIZE uses the total assets alghoritm with data collected from the whole total assets by adding fixed assets and current assets to the company. The following is the formula of the Company Size:

\section{SIZE = Logarithm Natural of Total Asset}

\section{Debt to Asset Ratio (DAR)}

Debt to Asset Ratio is used to quantify financed company assets and the effect of debt on management assets. The following is the Debt to Asset Ratio formula:

$$
D A R=\frac{\text { Total Debt }}{\text { Total Assets }} \times 100 \%
$$

\section{Return On Assets Ratio (ROA)}

Return on Assets (ROA) of the company shows the company ability in making the profit from the assets owned. The higher profits from the company, making the company's profitability level is also higher. The following is the formula for the Return on Assets ratio.

$$
R O A=\frac{\text { Earning After Tax }}{\text { Total Asset }} \times 100 \%
$$

\section{Research Model}

In determining the effect of company size and debt to assess ratio on ROA, it is performed Multiple linear regression analysis with the formula:

$$
Y=a+b_{1} X_{1}+b_{2} X_{2}+e
$$

$$
\begin{aligned}
& \text { Descriptions: } \\
& \begin{array}{ll}
\mathrm{Y} & =\text { Dependent Variable } \\
a & =\text { Constanta } \\
\mathrm{b}_{1}, \mathrm{~b}_{2} & =\text { Coefficient Regression } \\
\mathrm{X}_{1}, \mathrm{X}_{2} & =\text { Independent Variable } \\
\mathrm{e} & =\text { Error }
\end{array}
\end{aligned}
$$

\section{RESULT AND DISCUSSION}

Equation of calculation model results of Multiple Linear Regression Analysis is as follows:

$$
\mathrm{Y}=-14,162+0,898 \mathrm{SIZE}-18,506 \mathrm{DAR}
$$

Table 2. Result of Partially test (T-test)

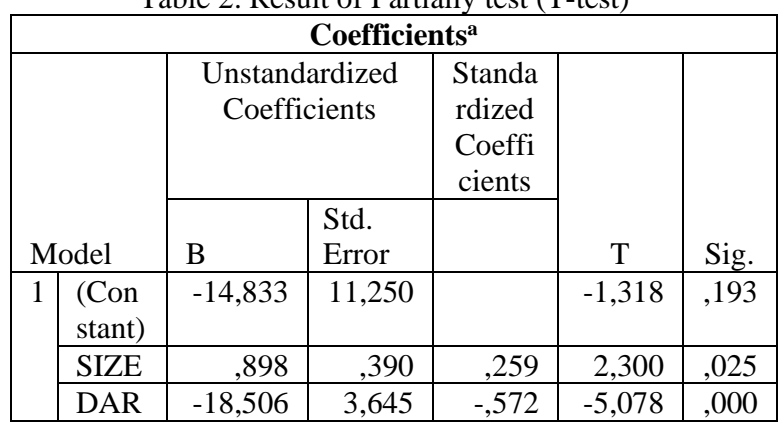

Source: Data process by SPSS, 2020

The results indicated that the significant value of $t_{\text {count }}$ in each variant will be compared with the $\mathrm{t}$ table results at $\mathrm{n}=58$ with a significance level of $5 \%$. At the error level $(\alpha=0,05)$ with the 2 -sided test, the free degree $(\mathrm{n}-\mathrm{k})$ or $58-2=56$ was obtained with a value of $t_{\text {table }}(56 ; 0,025)$ is 2,003 . The following are the t-results based on the effect of company size (SIZE) and debt to asset ratio (DAR) on return on assets (ROA) in the listed sub-sector of automotive manufacturing companies listed in the Indonesia Stock Exchange for the period 2014-2018:

1. Company Size (X1) Partially Influence on Return on Assets (Y)

$\mathrm{T}$ - test in table 2 obtained a significance value of $0,025<0,05$ then partially there is siginificant company size. While $t_{\text {count }} 2,300>$ $t_{\text {table }} 2,003$. It can be concluded that Ho is rejected and $\mathrm{Ha}$ is accepted Then the Company Size have a significant positive effect on Return On Assets.

The t- test shows a significance value of $0,025>0,05$. While the $t_{\text {count }} 2,300>t_{\text {table }} 2,003$. The effect is positive of 0,898 means that if there is an increase in Company Size, there will be an increase in ROA. Based on the results, Ho is rejected and $\mathrm{Ha}$ is accepted. It can be revealed that the company size influences on return on assets.

The results shows with the means, if the company has large size, it means that the company is able to produce high total asset. A high asset can support enterprises to optimize the performance of the company. Companies that improve performance, production levels may also increase. With increased production, the company can generate greater profits. The greater profit, the lower ROA.

This study results is in accordance with the study of (Azzahra \& Nasib, 2019; Meidiyustiani, 2016; Rusmawati, 2016), which shows that Company Size (Size) have a positive significant influence on Return On Assets (ROA).

2. Debt to Asset Ratio (X2) Partially Influence on Return On Asset (Y)

The $\mathrm{t}$ - test founded in table 2 obtained a significance value as much as $0,00<0,05$ then partially there is a significant debt ratio While the value of $t_{\text {count }}<t_{\text {table }}=-5,078<2,003$. Thus it can be concluded that $\mathrm{Ho}$ is accepted and $\mathrm{Ha}$ is 
rejected. There is significant negative effect between DAR and ROA.

This study obtained significance value of $0,00<0,05$ then partially DAR on ROA. While the value of $t_{\text {count }}<t_{\text {table }}=-5,078<2,003$. This value has a negative effect $-18,506$ meaning that if there is an increase in Debt to Asset Ratio (DAR), Return On Assets (ROA) will decrease. Based on the data, Ho is rejected and $\mathrm{Ha}$ is accepted. There is significant negative effect of ROA on DAR on Assets in listed automotive subsector manufacturing in Indonesia Stock Exchange period 2014-2018.

DAR illustrates the capital structure of the company as business funding source. A negative of DAR means the higher DAR, the higher company composition of the company's debt compared to the assets so that there is a large impact on the company's burden on outsiders because it may increase the debt payment. It is because the company will fulfill the obligations before making a profit. The higher the debt of the asset ratio reflects the higher risk of company and it shows the decline of ROA.

This results is in accordance with the study of (ALghusin, 2015; Kartikasari \& Merianti, 2016; Rusmawati, 2016) which shows that there is significant negative effect of DAR on ROA.

Table 3. Result of Simultaneously Test (F Test)

\begin{tabular}{|l|l|r|r|r|r|l|}
\hline \multicolumn{7}{|c|}{ ANOVA $^{\mathrm{a}}$} \\
\hline \multirow{2}{*}{\begin{tabular}{l} 
Model \\
\multirow{2}{*}{1}
\end{tabular}} & $\begin{array}{c}\text { Sum of } \\
\text { Squares }\end{array}$ & Df & $\begin{array}{c}\text { Mean } \\
\text { Square }\end{array}$ & F & Sig. \\
\cline { 2 - 8 } & Regression & 660,164 & 2 & 330,082 & 13,677 &, $000^{\mathrm{b}}$ \\
\cline { 2 - 8 } & Residual & 1327,409 & 55 & 24,135 & & \\
\cline { 2 - 7 } & Total & 1987,572 & 57 & & & \\
\hline
\end{tabular}

Source: Data process by SPSS, 2020

Based on the test result above, the variable Company Size (SIZE) and Debt to Asset Ratio (DAR) simultaneously influence the ROA. The value of $F_{\text {count }}$ as much as 13,677 which is the $F_{\text {table }}$ with the freedom degree in significance value $5 \%$ is $\mathrm{df} 1=2$ and $\mathrm{df} 2=55$, so $F_{\text {table }}$ is $F(2 ; 55)=3,160$. Then $F_{\text {count }}$ and $F_{\text {table }}$ are compared so that the value $13,677>3,160$ is obtained that $F_{\text {count }}$ is higher than $F_{\text {table. The significance value }}$ in SPSS is 0,00 which is smaller than 0,05 which means that Ho rejected and Ha do not rejected. Thus, it can be conclude that company size and debt to asset ratio together influence the ROA.

The results of the Company Size and DAR simultaneously influence on Return ROA, it can be seen that the $\mathrm{F}_{\text {count }}$ is 13,677 which $\mathrm{F}_{\text {table }}$ is obtained with free degrees at the $5 \%$ significance level df1 $=2$ and df $2=55$ then $\mathrm{F}_{\text {table }}$ obtained $\mathrm{F}(2 ; 55)=3,160$.

Then $F_{\text {count }}$ and $F_{\text {table }}$ compared and the value $13,677>3,160$ obtained that $F_{\text {count }}$ is higher than $F_{\text {table }}$. The significance value in SPSS is 0,00 which is smaller than 0,05 , that means that Ho is rejected and
$\mathrm{Ha}$ is accepted. Thus, it can be concluded that Company Size and Debt to Asset Ratio simultaneously have an influence on Return On Assets.

This results are in accordance with (Kartikasari \& Merianti, 2016) that shows that Company Size and Debt to Asset Ratio (DAR) simultaneously influence on ROA.

Table 4. Result of Determination Coefficient Test $\left(\mathrm{R}^{2}\right)$

\begin{tabular}{|l|c|c|l|l|l|}
\hline \multicolumn{7}{|c|}{ Model Summary } \\
\hline $\begin{array}{c}\text { Mo } \\
\text { del }\end{array}$ & $\mathrm{R}$ & $\mathrm{R}^{2}$ & $\begin{array}{l}\text { Adjusted } \\
\text { R Square }\end{array}$ & $\begin{array}{l}\text { Std. Error of } \\
\text { the Estimate }\end{array}$ & $\begin{array}{l}\text { Durbin- } \\
\text { Watson }\end{array}$ \\
\hline 1 &, $576^{\mathrm{a}}$ &, 332 &, 308 & 4,91271 & 1,831 \\
\hline
\end{tabular}

Source: Data process by SPSS, 2020

Table 4 shows that the $\mathrm{R}$ Square $\left(\mathrm{R}^{2}\right)$ is 0,332. It shows that the Return On Assets is influenced by 2 independent variable such as Company Size and Debt to Assets Ratio as much as $33,2 \%$ while the remaining as much as $66,8 \%$ is influenced by other variables with not involved variables.

\section{CONCLUSION}

The large size company means that the company is able to get high total asset. A high asset can support company to optimize the performance of the company. Companies that improve performance, production levels may also increase. With increased production, the company can generate greater profits. A greater profit can increase return on assets. So company size can influence the ROA. This research in according with the research conducted by (Azzahra \& Nasib, 2019) that shows that Company Size (Size) has an influence on Return On Assets (ROA).

Company DAR illustrates the company's capital structure used as a source of business funding. A negative debt ratio assets indicates that the higher the debt to asset ratio shows the higher the composition of the company's debt compared to the assets so that it has the large impact on the load of company on paying the debt. It is because the company will try to fulfill its debt obligations before making a profit. The higher DAR the higher risk of the company, it results the decrease of assets return. Thus the debt of asset ratio can effect of return on assets. The results of this research is in accordance with the research conducted by (Kartikasari \& Merianti, 2016) that shows that DAR has an influence on Return On Assets (ROA).

The total asset to classify big or small a company and DAR has influence on the company ability in making the profit. This results is in accordance with the research conducted by 
(Kartikasari \& Merianti, 2016) that shows that Company Size and Asset Ratio (DAR) simultaneously have an effect on ROA. So, the company should keep the stability of the company size and expect to perform debt management properly to optimize increasing the level of Return On Assets (ROA) and remain stable.

\section{REFERENCES}

ALghusin, N. A. S. (2015). Do Financial Leverage , Growth and Size Affect Profitability of Jordanian Industrial Firms Listed? International Journal of Academic Research in Business and Social Sciences, 5(4), 385-398. https://doi.org/10.6007/IJARBSS/v5-i4/1580

Azzahra, A. S., \& Nasib, N. (2019). PENGARUH FIRM SIZE DAN LEVERAGE RATIO TERHADAP KINERJA KEUANGAN PADA PERUSAHAAN PERTAMBANGAN. JWEM STIE MIKROSKIL, 9(1), 13-20.

Darmawan, A., \& Nurochman, A. D. (2016). PENGARUH CURRENT RATIO DAN DEBT TO ASSET RATIO. Jurnal Studia Akuntansi Dan Bisnis, 4(2), 57-66.

Halim, A. (2015). Manajemen Keuangan Bisnis: Konsep dan Aplikasinya. Jakarta: Mitra Wacana Media.

Hery. (2015). Analisis Laporan Keuangan. Yogyakarta: Center For Academy Publishing Services.

Kartikasari, D., \& Merianti, M. (2016). The Effect of Leverage and Firm Size to Profitability of Public Manufacturing Companies in Indonesia. International Journal of Economics and Financia Issues, 6(2), 409-413.

Kasmir. (2012). Analisis Laporan Keuangan. Jakarta: PT. Raja Grafindo Persada.

Kasmir. (2016). Pengantar Manajemen Keuangan. Jakarta: Prenada Media Group.
Mailinda, R., Azharsyah, A., \& Zainul, Z. R. (2018). PENGARUH LEVERAGE , LIKUIDITAS DAN UKURAN PERUSAHAAN TERHADAP PROFITABILITAS PADA BNI SYARIAH DI INDONESIA PERIODE 2015-2017. Jurnal Ilmihan Mahasiswa Ekonomi Manajemen, 3(4), 147-160.

Meidiyustiani, R. (2016). PENGARUH MODAL KERJA, UKURAN PERUSAHAAN, PERTUMBUHAN PENJUALAN DAN LIKUIDITAS TERHADAP PROFITABILITAS PADA PERUSAHAAN MANUFAKTUR SEKTOR INDUSTRI BARANG KONSUMSI YANG TERDAFTAR DI BURSA EFEK INDONESIA (BEI) PERIODE TAHUN 2010 - 2014. Jurnal Akuntansi Dan Keuangan, 5(2), 161-179.

Nurdiana, D. (2018). Pengaruh Ukuran Perusahaan Dan Likuiditas Terhadap Profitabilitas. Menara Ilmu, XII(6), 77-88.

Purnamasari, D. A., \& Fitria, A. (2015). Pengaruh Perputaran Piutang dan Ukuran Perusahaan Terhadap Profitabilitas Perusahaan Kimia. Ilmu dan Riset Akuntansi, 4(8).

Riyanto, B., 2013. Dasar-Dasar Pembelanjaan Perusahaan. 4 ed. Yogyakarta: BPFEYogyakarta.

Sujarweni, V. W. (2015). Akuntansi Manajemen. Yogyakarta: Pustaka Baru Press.

Sutrisno. (2013). Manajemen Keuanga: Teori Konsep dan Aplikasi. Yogyakarta: Ekonisia.

Rusmawati, Y. (2016). PENGARUH UKURAN PERUSAHAAN, STRUKTUR HUTANG, DAN UMUR PERUSAHAAN TERHADAP PROFITABILITAS PADA PERUSAHAAN FOOD \& BEVERAGES DI BURSA EFEK INDONESIA TAHUN 2012-2014. Jurnal Penelitian Ekonomi Dan Akuntansi, I(2), 111126.

Zulkarnaen, Z. (2018). PENGARUH DEBT TO ASSETS RATIO TERHADAP RETURN ON ASSET PADA PERUSAHAAN ASURANSI YANG TERDAFTAR DI BEI TAHUN 2010 2015. Jurnal Warta, 56(April), 1-11. 